\title{
A new spider genus (Araneae: Linyphiidae: Erigoninae) from a tropical montane cloud forest of Mexico
}

\author{
Guillermo IBARRA-NÚÑEZ ${ }^{1, *}$, David CHAMÉ-VÁZQUEZ ${ }^{2}$ \& Julieta MAYA-MORALES ${ }^{3}$ \\ ${ }^{1,2,3}$ El Colegio de la Frontera Sur, Unidad Tapachula. Carretera Antiguo Aeropuerto km 2.5, \\ Apdo. Postal 36, Tapachula, Chiapas 30700, Mexico. \\ *Corresponding author: gibarra@ecosur.mx \\ ${ }^{2}$ Email: chamevazquez@gmail.com \\ 32Email: dianobi@yahoo.com

\footnotetext{
${ }^{1}$ urn:1sid:zoobank.org:author:61F4CDEF-04B8-4F8E-83DF-BFB576205F7A

${ }^{3}$ urn:1sid:zoobank.org:author:BE1F67AB-94A6-45F7-A311-8C99E16139BA
} \\ ${ }^{2}$ urn:1sid:zoobank.org:author:CDA7A4DA-D0CF-4445-908A-3096B1C8D55D
}

\begin{abstract}
A new genus and species of spider (Araneae, Linyphiidae, Erigoninae) from a tropical montane cloud forest of Mexico is described from both male and female specimens, Xim trenzado gen. et sp. nov. A phylogenetic parsimony analysis situates Xim gen. nov. as a distinct genus among the distal Erigoninae. Xim gen. nov. is sister to a clade including Ceratinopsis, Tutaibo and Sphecozone, but differs from those genera by having a high cymbium, large paracymbium, short straight embolus, male cheliceral stridulatory striae widely and evenly spaced, both sexes with a post-ocular lobe, male with two series of prolateral macrosetae on femur I, and the female by having strongly oblong, u-shaped spermathecae.
\end{abstract}

Keywords. Chiapas, cloud forest understory, systematics, taxonomy.

Ibarra-Núñez G., Chamé-Vázquez D. \& Maya-Morales J. 2021. A new spider genus (Araneae: Linyphiidae: Erigoninae) from a tropical montane cloud forest of Mexico. European Journal of Taxonomy 731: 97-116. https://doi.org/10.5852/ejt.2021.731.1207

\section{Introduction}

Hoffmann (1976) enumerated 18 genera and 67 species for the family Linyphiidae Blackwall, 1859 in Mexico. Currently, 24 genera and 105 species of Linyphiidae are cited from Mexico (Banks 1898; Chamberlin 1924; Gertsch \& Davis 1937, 1946; Dondale 1959; Millidge 1980, 1987; Prentice \& Redak 2013; WSC 2020) whereas the rest of North America (Canada and USA) has 174 genera and 937 species (Draney \& Buckle 2017). Llorente et al. (1996) estimated the arthropod fauna of Mexico as three times as rich as that of the rest of North America, but in the case of Linyphiidae, the available information gives an opposite perspective. Miller (2007) reviewed the taxonomy of the Erigoninae Emerton, 1882 subfamily of Linyphiidae for the Neotropical region including 50 genera, of which he considered 39 as endemic to the Neotropics, but he stated that "Central American and Mexican linyphiids remain poorly 
known." Among the Erigoninae, 12 genera are cited for Mexico, five of these correspond to Nearctic or Holarctic genera (Ceraticelus Simon, 1884, Eridantes Crosby \& Bishop, 1933, Eulaira Chamberlin \& Ivie, 1933, Idionella Banks, 1893 and Spirembolus Chamberlin, 1920) and only one (Toltecaria Miller, 2007) is endemic to the Neotropics (Miller 2007; Prentice \& Redak 2013). As North America and South America have a prominent richness of linyphiid species, the current reduced number of Mexican records does not seem to approximate the true richness of this family. Instead, it could be due more to a scarcity of sampling of spiders in Mexico, or the need to sample in the adequate habitats for this family, as there are indications that in some tropical regions the linyphiids increase in abundance and richness with altitude (Russell-Smith \& Stork 1994; Sørensen 2004; Miller 2007).

The phylogeny of the Erigoninae has been analyzed by parsimony methods by Hormiga (2000), followed by Miller \& Hormiga (2004) who made a comprehensible analysis encompassing 82 taxa with 176 characters. The matrix of Miller \& Hormiga (2004) was later used by different authors to find the phylogenetic placement of several additional Erigoninae taxa (Miller 2005a, 2005b; Dupérré \& Paquin 2007; Paquin et al. 2008; Frick \& Muff 2009; Seyfulina \& Jocqué 2009; Frick et al. 2010). Other authors analyzed the Linyphiidae phylogeny using a combination of morphological and molecular characters (Arnedo et al. 2009), or only molecular characters (Wang et al. 2015; Zhao \& Li 2017), but the number of Erigoninae genera analyzed is reduced $(6,33,13)$ in comparison with Frick et al. (2010) (81 Erigoninae genera), as is the number of genera shared by those studies with Frick et al. (2010) (6, $10,12)$, limiting a useful comparison between those phylogenies. In this work, we describe a new spider genus and species of Erigoninae found in a tropical mountain cloud forest in Chiapas, Mexico. Due to the exceptional characters found in Xim trenzado gen. et sp. nov., the morphology of this species was scored following the character matrix of Miller \& Hormiga (2004), as modified by Frick et al. (2010), and subsequently analyzed to find its position within the Erigoninae.

\section{Material and methods}

\section{Material}

Specimens are deposited in the following institutions:

$\begin{array}{ll}\text { AMNH } & \text { American Museum of Natural History, New York, USA } \\ \text { CAS } & =\text { California Academy of Sciences, San Francisco, California, USA } \\ \text { CNAN } & =\text { Instituto de Biología, UNAM, Ciudad de México, Mexico } \\ \text { ECOTAAR } & \text { El Colegio de la Frontera Sur, Tapachula, Chiapas, Mexico } \\ \text { MACN } & =\text { Museo Argentino de Ciencias Naturales, Buenos Aires, Argentina } \\ \text { MNHN } & =\text { Muséum national d'histoire naturelle, Paris, France } \\ \text { USNM } & =\text { National Museum of Natural History, Smithsonian Institution, Washington, D.C., USA } \\ \text { ZMB } & =\text { Museum für Naturkunde, Berlin, Germany }\end{array}$

\section{Measurement and preparation}

Morphological observations, measurements, photographs and drawings were made with a Nikon SMZ 1500 stereo microscope, an Olympus SZX16 stereo microscope, provided with a Sony Alfa 58 camera, a Nikon Eclipse E400 compound microscope and a Carl Zeiss Axio Imager A1 compound microscope. Measurements were made with a micrometric ocular and are giving in millimeters, leg measurements from the dorsal side are noted as: leg number total length (femur, patella, tibia, metatarsus, tarsus). Color pattern descriptions were made on specimens preserved in $80 \%$ ethanol. A female specimen was used to analyze the tracheal system, its opisthosoma was longitudinally opened by the dorsal side, digested with a solution made with eye-lens cleaner (half a tablet of AMO Ultrazyme with Subtilisin A, diluted in $1 \mathrm{ml}$ of distilled water), left overnight, washed with distilled water and placed in ethanol $80 \%$ the next morning. Female genitalia were dissected and later cleaned with a subtilisin solution as 
for the tracheal system. Palpi and epigyna were examined with a compound microscope using methyl salicylate as a temporary clearing agent. SEM images were made with a TOPCON SM-510 scanning electron microscope at El Colegio de la Frontera Sur (ECOSUR), Unidad Tapachula. Specimens used for obtaining SEM images were previously dehydrated in an ethanol series, dried to critical point, mounted on aluminum stubs and then coated with gold/palladium.

\section{Phylogenetic analysis}

In order to explore the phylogenetic placement of Xim trenzado gen. et sp. nov. among the Erigoninae, we scored its morphology based on the character matrix of Miller \& Hormiga (2004) (Table 1). Characters 135 (Femur I prolateral macrosetae), 136 (Tibia I proximal dorsal macroseta) and 138 (Tibia II proximal dorsal macroseta) were coded as polymorphic (among brackets) because they differed for each sex. We appended the character codings of this species to the matrix of Frick et al. (2010, available from TreeBASE M5022), which is based on the matrix of Miller \& Hormiga (2004). The resulting matrix (176 characters by 112 taxa) was analyzed using TNT ver. 1.5 (Goloboff \& Catalano 2016), with multistate characters treated as non-additive, memory space set to 10000 trees, performing a traditional search (1000 replications of TBR, saving 10 trees per replication and collapsing trees after the search). Bremer support was calculated in TNT based on all most parsimonious trees, with TBR search and retaining the suboptimal trees up to 16 steps longer. Winclada (Nixon 2002) was used to generate the character optimization tree.

Abbreviations (based on Miller \& Hormiga 2004 and Miller 2007)

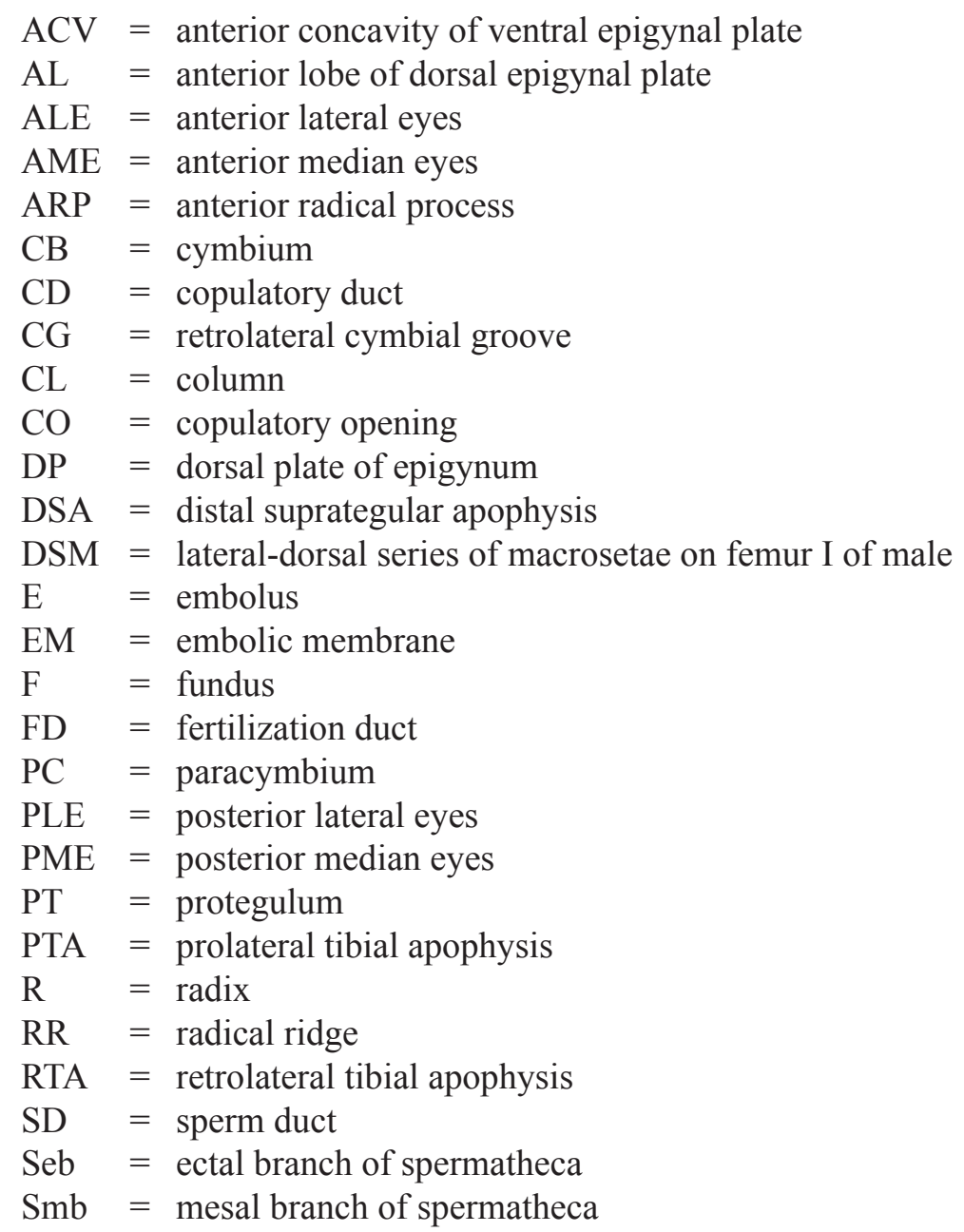


Table 1. Character coding for Xim trenzado gen. et sp. nov., according to the characters given by Miller \& Hormiga (2004). Characters 135 (Femur I prolateral macrosetae), 136 (Tibia I proximal dorsal macroseta) and 138 (Tibia II proximal dorsal macroseta) were coded as polymorphic (among brackets) because they differed for each sex. Abbreviations: character coding $=$ C.C.; character number $=$ C.N.

\begin{tabular}{|c|c|c|c|c|c|c|c|c|c|c|}
\hline C.N. & (1) & (2) & (3) & (4) & (5) & (6) & (7) & (8) & (9) & (10) \\
\hline C.C. & 0 & - & 0 & 0 & 0 & 0 & 1 & 0 & 1 & 0 \\
\hline C.N. & (11) & (12) & (13) & (14) & $(15)$ & (16) & (17) & (18) & (19) & (20) \\
\hline C.C. & 0 & 4 & 0 & 1 & 0 & 1 & 0 & - & 0 & 1 \\
\hline C.N. & (21) & (22) & $(23)$ & (24) & $(25)$ & $(26)$ & (27) & (28) & (29) & $(30)$ \\
\hline C.C. & 1 & 0 & 1 & 1 & 0 & 0 & 0 & 0 & 1 & 0 \\
\hline C.N. & (31) & (32) & (33) & (34) & (35) & (36) & (37) & (38) & (39) & (40) \\
\hline C.C. & 1 & 0 & 0 & 0 & 1 & 1 & 0 & 1 & 0 & 1 \\
\hline C.N. & (41) & (42) & $(43)$ & (44) & $(45)$ & $(46)$ & (47) & (48) & (49) & $(50)$ \\
\hline C. C. & 0 & 0 & 1 & - & 0 & 0 & 1 & 0 & 0 & 1 \\
\hline C.N. & (51) & $(52)$ & $(53)$ & (54) & $(55)$ & $(56)$ & $(57)$ & (58) & $(59)$ & $(60)$ \\
\hline C.C. & 1 & 1 & 1 & 0 & 1 & 0 & 0 & 0 & 0 & 1 \\
\hline C.N. & (61) & (62) & (63) & (64) & $(65)$ & $(66)$ & (67) & (68) & (69) & (70) \\
\hline C.C. & 0 & - & 1 & 0 & 0 & 0 & 1 & 0 & 0 & 1 \\
\hline C.N. & (71) & (72) & $(73)$ & (74) & $(75)$ & $(76)$ & (77) & (78) & (79) & $(80)$ \\
\hline C.C. & 0 & 0 & 2 & 3 & 0 & 0 & 0 & 0 & 0 & 1 \\
\hline C.N. & (81) & (82) & (83) & (84) & $(85)$ & (86) & (87) & (88) & (89) & (90) \\
\hline C.C. & 0 & - & 0 & 0 & 0 & 0 & 0 & 0 & 0 & 0 \\
\hline C.N. & (91) & (92) & (93) & (94) & (95) & (96) & (97) & (98) & (99) & (100) \\
\hline C.C. & 0 & 0 & 1 & 0 & 0 & 0 & 0 & 1 & 0 & 0 \\
\hline C.N. & (101) & (102) & (103) & (104) & (105) & (106) & (107) & (108) & (109) & (110) \\
\hline C.C. & 0 & 0 & 1 & 0 & 0 & 0 & 0 & 0 & 0 & 0 \\
\hline C.N. & (111) & (112) & (113) & (114) & (115) & (116) & (117) & (118) & (119) & (120) \\
\hline C.C. & 2 & $?$ & 1 & 0 & 0 & 1 & 1 & 0 & $?$ & 0 \\
\hline C.N. & (121) & $(122)$ & (123) & (124) & (125) & (126) & (127) & (128) & (129) & (130) \\
\hline C.C. & 0 & 0 & 4 & 1 & 0 & 1 & 0 & 0 & 0 & 0 \\
\hline C.N. & (131) & (132) & (133) & (134) & (135) & (136) & (137) & (138) & (139) & (140) \\
\hline C.C. & 2 & 1 & 1 & 0 & {$[10]$} & {$[01]$} & 0 & [01] & 0 & 1 \\
\hline C.N. & (141) & (142) & (143) & (144) & (145) & (146) & (147) & (148) & (149) & (150) \\
\hline C.C. & 0 & 1 & 0 & 0 & 0 & 0 & 0 & 0 & 0 & 0 \\
\hline C.N. & $(151)$ & $(152)$ & (153) & (154) & (155) & (156) & (157) & (158) & (159) & (160) \\
\hline C.C. & 0 & 0 & 1 & $?$ & 0 & 0 & 1 & 1 & 1 & 1 \\
\hline C.N. & (161) & (162) & (163) & (164) & (165) & (166) & (167) & (168) & (169) & (170) \\
\hline C.C. & $?$ & 2 & 0 & 1 & 1 & 1 & 0 & 0 & 0 & - \\
\hline C.N. & (171) & (172) & (173) & (174) & (175) & (176) & & & & \\
\hline C.C. & $?$ & $?$ & $?$ & 0 & $?$ & 0 & & & & \\
\hline
\end{tabular}




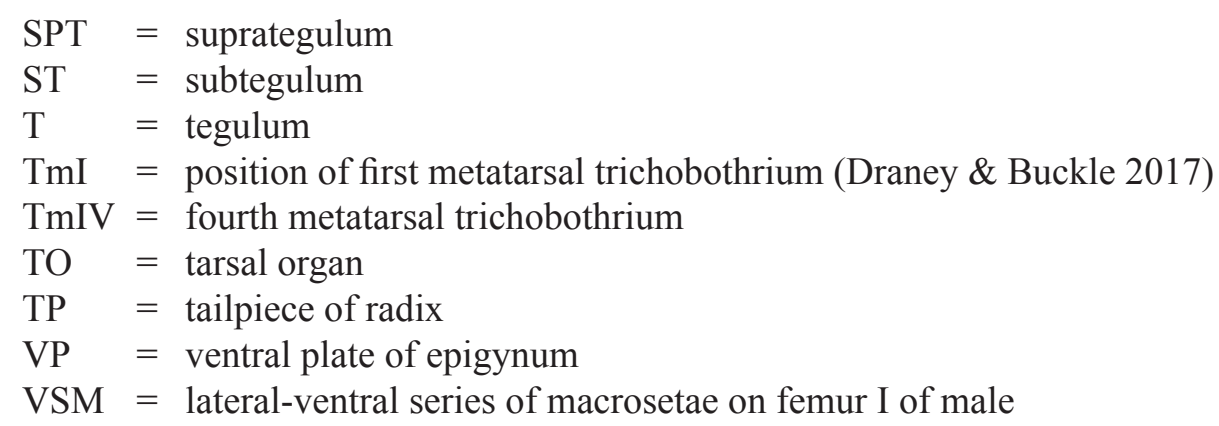

\title{
Results
}

\author{
Class Arachnida Cuvier, 1812 \\ Order Araneae Clerck, 1757 \\ Family Linyphiidae Blackwall, 1859 \\ Subfamily Erigoninae Emerton, 1882 \\ Xim gen. nov. \\ urn:lsid:zoobank.org:act:E6CE6724-C10E-47E9-BC3A-9FC415514958
}

Figs 1-5

\section{Type species}

Xim trenzado gen. et sp. nov. by monotypy and present designation.

\section{Diagnosis}

Xim gen. nov. is sister to a clade including Ceratinopsis Emerton, 1882, Tutaibo Chamberlin, 1916 and Sphecozone O. Pickard-Cambridge, 1871. Xim gen. nov. shares with each of these three genera a subtegulum ectal to the tegulum (Figs 2C, F, 3A), a membranous connection between radix and embolus (Fig. 2B), embolus originated from radix at a distinct angle (Figs 2B, E, H-I, 3B), a short, entire epigynum (Fig. 5A-B, G), fertilization duct separated from copulatory duct (Fig. 5H), and copulatory openings at the dorsal plate-ventral plate junction (Fig. 5A-B). Additionally, Xim gen. nov. shares with Ceratinopsis and Tutaibo an intersegmental, straight-hook paracymbium (Fig. 2C, F), a tegulum with papillae (Fig. 2B-C, E-F, H), a spiral radical tailpiece (Figs 2A-B, D-E, 3B) and a radical ridge (Figs 2E, H-I, 3B). Xim gen. nov. differs from each of those three genera by having a high cymbium (Figs 1B, 2A, C-D, F), a large paracymbium (Figs 2A-F, 3A), a very short straight embolus (Figs 2B, E, H-I, 3B), male cheliceral stridulatory striae scaly, widely and evenly spaced, both sexes with a post-ocular lobe (Fig. 1B, E), male with two series of prolateral macrosetae on femur I (Figs 1A-B, 4A-G), and the female by having strongly oblong, u-shaped spermathecae (Fig. 5C-H). Furthermore, Xim gen. nov. differs from Ceratinopsis by lacking trichobothria on the prolateral side of palpal tibia, by having a retrolateral tibial apophysis (Fig. 2C, F) and the dorsal plate of epigynum with an anterior lobe flush with the ventral plate (Fig. 5A-B, G); from Tutaibo by lacking a cymbial basal excavation and a tegular sclerite on the anterior part of the tegulum, by having a cymbium retrolateral groove (Fig. $2 \mathrm{C}, \mathrm{F}-\mathrm{H})$, an embolic membrane (Figs 2E, H-I, 3B), copulatory ducts not encapsulated (Fig. 5C-F, H) and male lacking a proximal dorsal macroseta on the tibiae I and II; from Sphecozone by having a paracymbium (Figs 2A-F, 3A), a cymbial retrolateral groove (Fig. 2C, F-H), by lacking a cymbial basal excavation, and by lacking an epigynal atrium.

\section{Etymology}

The genus is named after the word spider in the Mam language, whose native speakers inhabit the border area between Mexico and Guatemala. The gender is masculine. 


\section{Description}

Body. Small (1.49-1.91), light brown; post-ocular lobe conical, lower in females; AER and PER slightly recurved; male with prolateral macrosetae on femur I; leg formula 1423.

MALE PALP. Tibia with conspicuous prolateral apophysis, small retrolateral apophysis and one retrolateral trichobothrium; cymbium with prolateral and dorsal processes; paracymbium large; tegulum elliptical; radix with spiral tailpiece and serrated ridge; embolus very short and straight.

EPIGYNum. Ventral plate large, ovoid with anterior semicircular concavity; dorsal plate small rectangular and transverse with large anterior lobe; copulatory openings as narrow slits between ventral plate and anterior lobe of dorsal plate; copulatory ducts short and wide; spermathecae oblong, u-shaped with one mesal and one ectal branch; fertilization ducts small.

\section{Phylogenetic relationships and justification of monotypy}

Our phylogenetic analysis yielded eight equally most parsimonious trees (L 1096, CI 0.19, RI 0.58; excluding uninformative characters 104 and 155: L 1094). The topology of the strict consensus of these trees (L 1099, CI 0.19, RI 0.58) is identical to the consensus tree of Frick et al. (2010), except that here (and in each of the eight most parsimonious trees) Xim trenzado gen. et sp. nov. is sister to a clade that includes Ceratinopsis, Tutaibo and Sphecozone (Figs 6-7), corresponding to clades 76 of Miller \& Hormiga (2004) and 62 of Frick et al. (2010). Circumscribing Xim trenzado gen. et sp. nov. within a polytypic genus would require synonymization of these three genera. Nevertheless, Miller \& Hormiga (2004: 402) stated that the monophyly of Sphecozone and Tutaibo are not in doubt and are clearly diagnosable. The phylogenetic analysis supports, with nine unambiguous characters, the hypothesis that Xim trenzado gen. et sp. nov. is not congeneric with the genera included in clade 76 of Miller \& Hormiga (2004), making necessary a new genus for this species. The nine unambiguous characters of Xim trenzado gen. et sp. nov. are: cymbium as tall as long (9-1); sperm duct path in distal part of tegulum with thigh kink (23-1), embolus short (43-1), initial orientation of PTA perpendicular (68-0), RTA present (70-1), male with a post-ocular, conical lobe (103-1), cheliceral stridulatory striae scaly (117-1), female palpal tarsus without proximal dorsomesal macrosetae (127-0), female palpal tarsus with one ventroectal macrosetae (132-1).

Xim trenzado gen. et sp. nov.

urn:1sid:zoobank.org:act:62BE28C7-8A47-4053-B6CD-EA2F7E5EA83B

Figs $1-5$

\section{Diagnosis}

Monotypic genus, see genus diagnosis.

\section{Etymology}

The specific epithet is a noun in apposition taken from the Spanish word meaning 'braided', referring to the interweaved macrosetae on the femur I of the male.

\section{Type material}

\section{Holotype}

MEXICO • गै; Chiapas, Municipio de Unión Juárez, Ejido Talquián; $15^{\circ} 05^{\prime} 15^{\prime \prime} \mathrm{N}, 92^{\circ} 05^{\prime} 56^{\prime \prime} \mathrm{W}$; 2010 m a.s.l.; 4 Mar. 2009; Maya, Ibarra, López and Sentíes leg.; tropical montane cloud forest, in low understory; beating; ECOTAAR-005030.

\footnotetext{
Allotype

MEXICO • + ; same collection data as for holotype; ECOTAAR-005030.
} 


\section{Paratypes}

MEXICO • 1 đ̂, 1 क; same collection data as for holotype; 22 Jan. 2009; Maya, Ibarra, López and Sentíes leg.; ECOTAAR-004936・1 Ô, 1 क; same collection data as for preceding; AMNH • 1 o, 1 क; same collection data as for preceding; 4 Feb. 2009; CNAN • 1 त, 1 \% ; same collection data as for preceding;

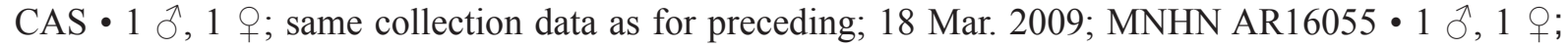
same collection data as for preceding; MACN $\bullet 1 \hat{\partial}, 1$; ; same collection data as for preceding; $1 \mathrm{Apr}$. 2009; USNM • 1 O , 1 क; same collection data as for preceding; 15 Jul. 2009; Maya, Ibarra and López leg.; ZMB Arach 49468.

\section{Other material}

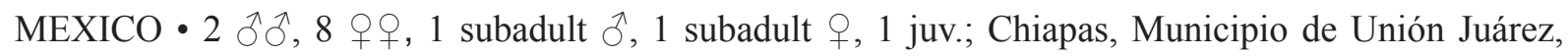
Ejido Talquián; $15^{\circ} 05^{\prime} 15^{\prime \prime} \mathrm{N}, 92^{\circ} 05^{\prime} 56^{\prime \prime} \mathrm{W} ; 2010$ m a.s.1.; 22 Jan. 2009; Maya, Ibarra, López and Sentíes leg.; tropical montane cloud forest, in low understory; beating; ECOTAAR-004937 • 1 ठ ; same collection data as for preceding; 4 Feb. 2009; ECOTAAR-004950 1 ㅇ, 2 juvs; same collection data as for preceding; ECOTAAR-004949・6 $\lesssim, 6$ 우, 1 subadult $\lesssim, 2$ juvs; same collection data as for

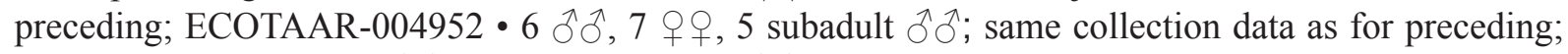

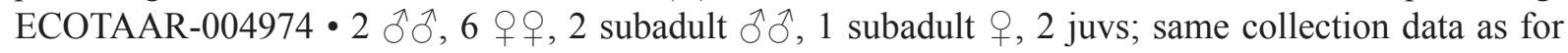
preceding; 4 Mar. 2009; ECOTAAR-005029 - 1 \%; same collection data as for preceding; 18 Mar.

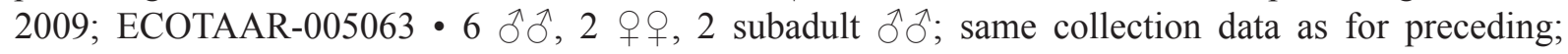
1 Apr. 2009; ECOTAAR-005177 • 1 \%; same collection data as for preceding; ECOTAAR-005183 - 1 O ; same collection data as for preceding; 12 Aug. 2009; Maya, Ibarra, López and Chamé leg.; ECOTAAR-005435 • 1 ते; same collection data as for preceding; hand collecting; ECOTAAR-005438 - 1 đ’; same collection data as for preceding; $15^{\circ} 05^{\prime} 38^{\prime \prime} \mathrm{N}, 92^{\circ} 06^{\prime} 06^{\prime \prime} \mathrm{W}$; $2044 \mathrm{~m}$ a.s.1.; 5 Feb. 2009;

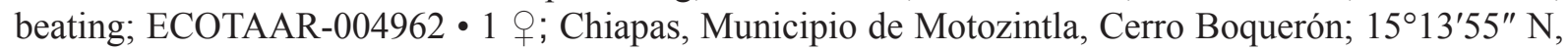
92 ${ }^{\circ} 18^{\prime} 22^{\prime \prime}$ W; 2332 m a.s.1.; 27 Feb. 2015; Campuzano, Montaño and Moreno leg.; tropical montane cloud forest, in low understory; beating; ECOTAAR-011462.

\section{Description}

\section{Male}

HABITUS. Carapace, chelicerae and endites light brown with some suffused grey on thoracic part, labium and sternum brown, distal half of labium light brown. Legs, coxae to femora yellow-cream with distal half of femur I and II light-brown, tibiae to tarsi yellow brown. Opisthosoma light brown with sparse yellow spots and slender yellow chevrons on the rear half of dorsum (Fig. 1A-C, G).

Measurements. Total length 1.68. Carapace 0.71 long, 0.59 wide.

Prosoma. Carapace with conical post-ocular lobe, about as high as clypeus in lateral view, apex crowned with few hairs. Eye diameters and interdistances: AME 0.039, ALE 0.052, PME 0.039, PLE 0.039, AME-AME 0.026, AME-ALE 0.065, PME-PME 0.065, PME-PLE 0.065; AER in frontal view almost straight, slightly recurved, PER in dorsal view almost straight, slightly recurved. Clypeus 0.13 high with few short setae below AME. Chelicerae with five promarginal (Fig. 1G) and four retromarginal teeth; lateral face of chelicerae with scaly striae, widely and evenly spaced. Sternum 0.40 long, 0.44 width, produced between coxae IV posterior tip truncated; coxae IV 1.4 times their width apart (Fig. 1C).

Opisthоsома. Elliptical, slightly narrowed towards posterior end (Fig. 1A-C).

LEGs. Femur I with distal half modified, bent ventrad, prolaterally enlarged, with hemispherical bulge about three quarters from femur base (Figs 1A-B, 4A-F). Distal, prolateral side of femur I with two longitudinal, parallel series of conspicuous macrosetae beginning at femoral turn, finishing at base of the hemispherical bulge (Fig. 4A-G). Dorso-lateral series of macrosetae composed of nine, spaced, erect, 


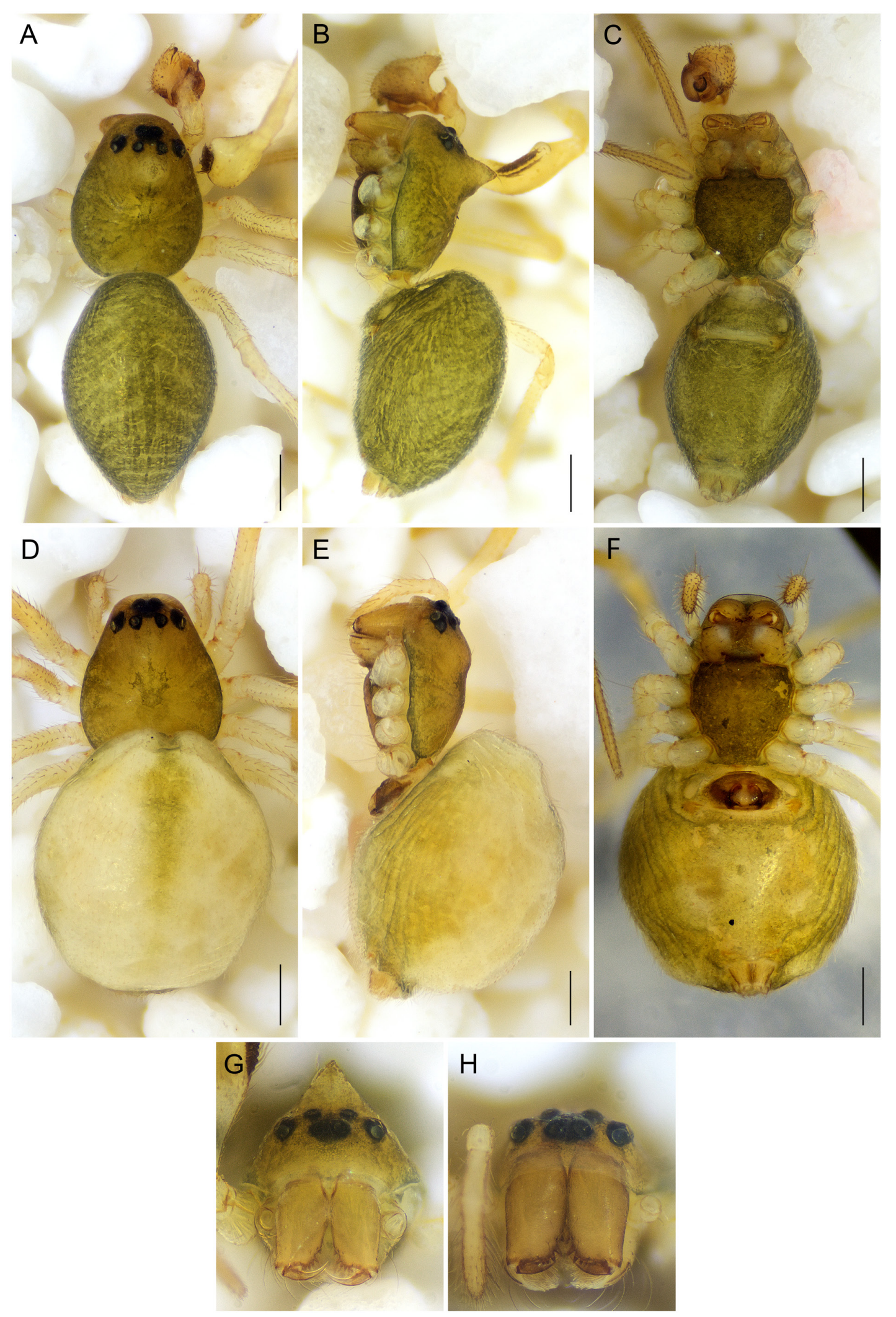

Fig. 1. Xim trenzado gen. et sp. nov. A-C, G. đ (ECOTAAR-004950). D-F, H. + (ECOTAAR-005063). A-F. Habitus. A, D. Dorsal view. B, E. Lateral view. C, F. Ventral view. G, H. Carapace in frontal view. Scale bars: A-F $=0.25 \mathrm{~mm}$. 

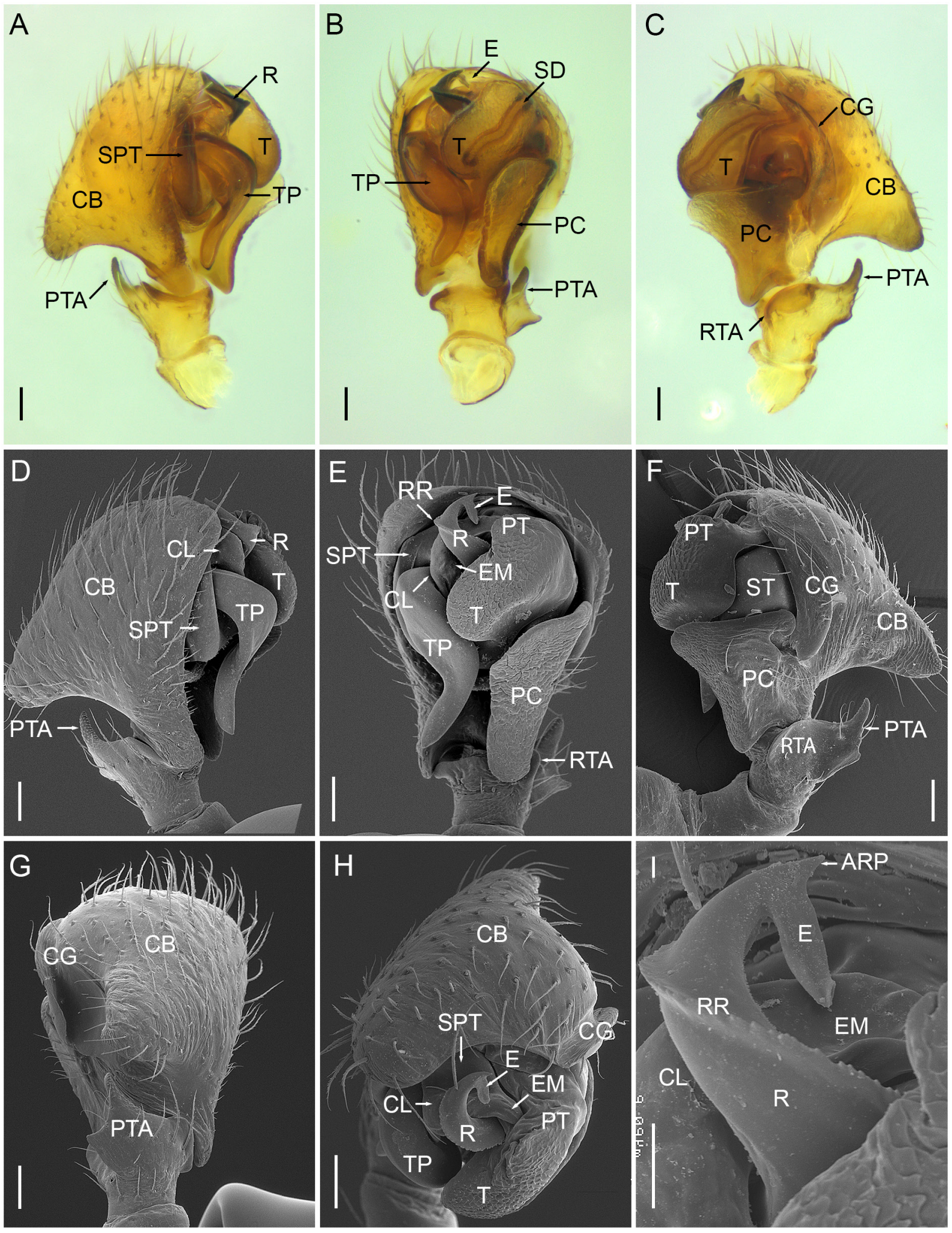

Fig. 2. Xim trenzado gen. et sp. nov., male left palpus. A-C. ECOTAAR-004974. D-E, G-I. ECOTAAR-004950. F. ECOTAAR-004952. A, D. Mesal view. B, E. Ventral view. C, F. Ectal view. G. Dorsal view. H. Apical view. I. Detail of E showing radix and embolus. Scale bars: A-E = $50 \mu \mathrm{m} ; \mathrm{F}=20 \mu \mathrm{m}$. 
macrosetae gently curved, ventro-lateral series composed of 18 (17 on right femur I) macrosetae closely spaced, recumbent, strongly curved, interweaved forming a braid (Fig. 4A-G). Tibiae I to II without dorsal macrosetae, tibiae III with one very short, proximal dorsal macroseta, tibiae IV with one short proximal, dorsal macroseta, without distal, dorsal macroseta; metatarsi and tarsi without macrosetae. Leg formula: 1423. Legs measurements: I 2.52 (0.70, 0.21, 0.61, 0.58, 0.42), II $2.36(0.71,0.19,0.57$, $0.53,0.36)$, III $1.80(0.56,0.16,0.38,0.43,0.27)$, IV $2.49(0.66,0.17,0.56,0.68,0.42)$; TmI 0.40 , TmIV absent.

PaLPus. Distal half of femur ventrally slightly enlarged; tibia with conspicuous plate-like, slanting, higher than long, prolateral apophysis pointed in distal corner (Figs 1B, 2A-D, F-G); with a small, rounded, distal retrolateral apophysis touching paracymbium (Fig. 2C, E-F); with one retrolateral trichobothrium (Figs 2F, 4I), lacking on prolateral side (Fig. 2D). Cymbium with deep retrolateral groove wider in proximal part (Fig. 2C, F-H), with an elongated, prolateral, basal process touching palpal tibia (Fig. 2A-B, D-E, $\mathrm{G}$ ) and a large slanted, pointed dorsal process with retrolateral face slightly concave, glabrous from apex till retrolateral cymbial groove, its prolateral face convex and hirsute as most of cymbium (Figs 1B, 2A, $\mathrm{C}-\mathrm{D}, \mathrm{F}-\mathrm{H}$ ). Alveolus nearly as long as cymbium. (Figs 2B, E, 3A). Paracymbium large with scale-like papillae, connected to cymbium by a membrane, longer than wide (wider distally), about half as long as cymbium, extended proximally to fit the RTA, distally overlapping proximal part of tegulum and about half of subtegulum, with few small setae near base and tip forming a straight hook touching retrolateral cymbial groove (Figs 2B-C, E-F, 3A). Subtegulum ectal to tegulum. Tegulum elliptical, with scale-

A

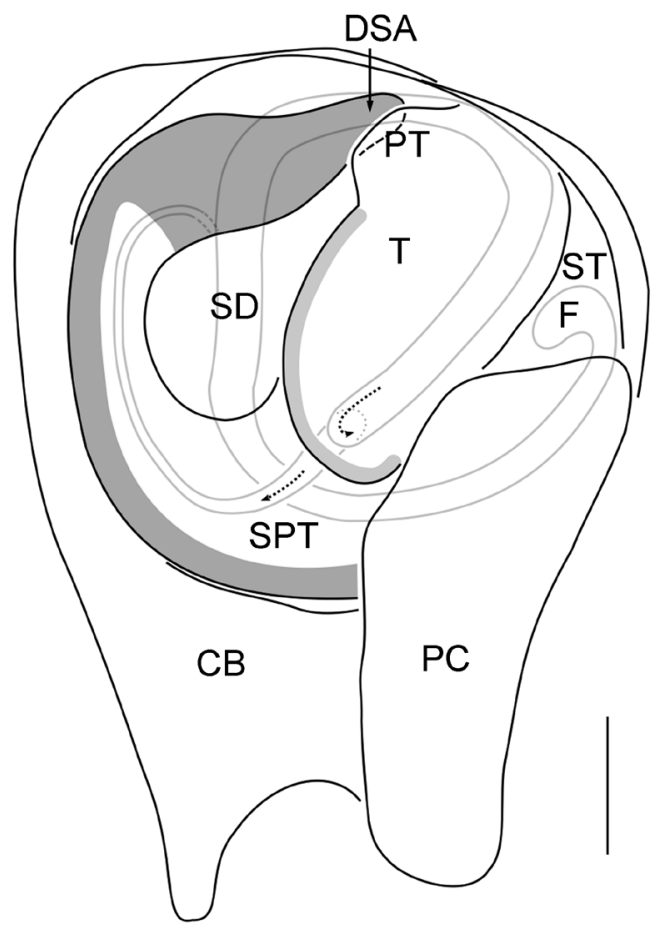

$\mathrm{B}$

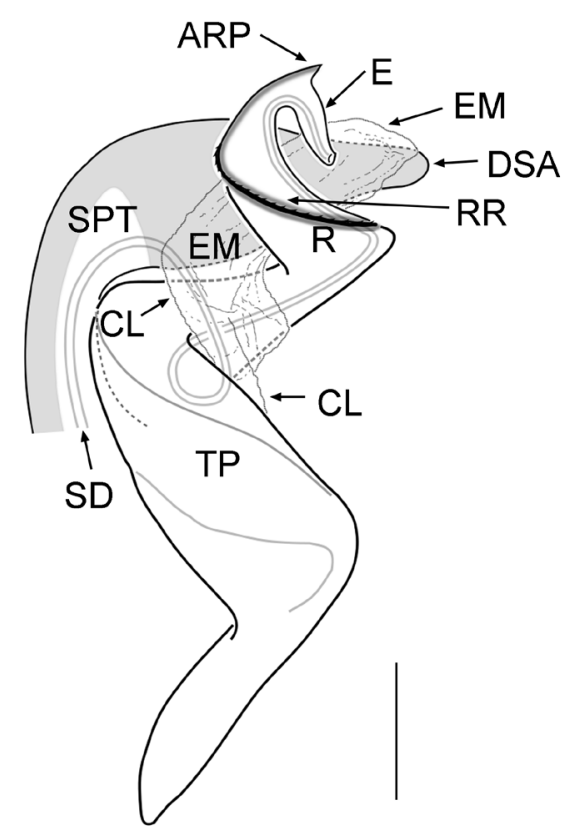

Fig. 3. Xim trenzado gen. et sp. nov., male left palpus, schematic. A. Palpus without embolic division, ventral view. B. Embolic division with part of distal suprategular apophysis, ventral view. Scale bars: A= $50 \mu \mathrm{m} ; \mathrm{B}=40 \mu \mathrm{m}$. 

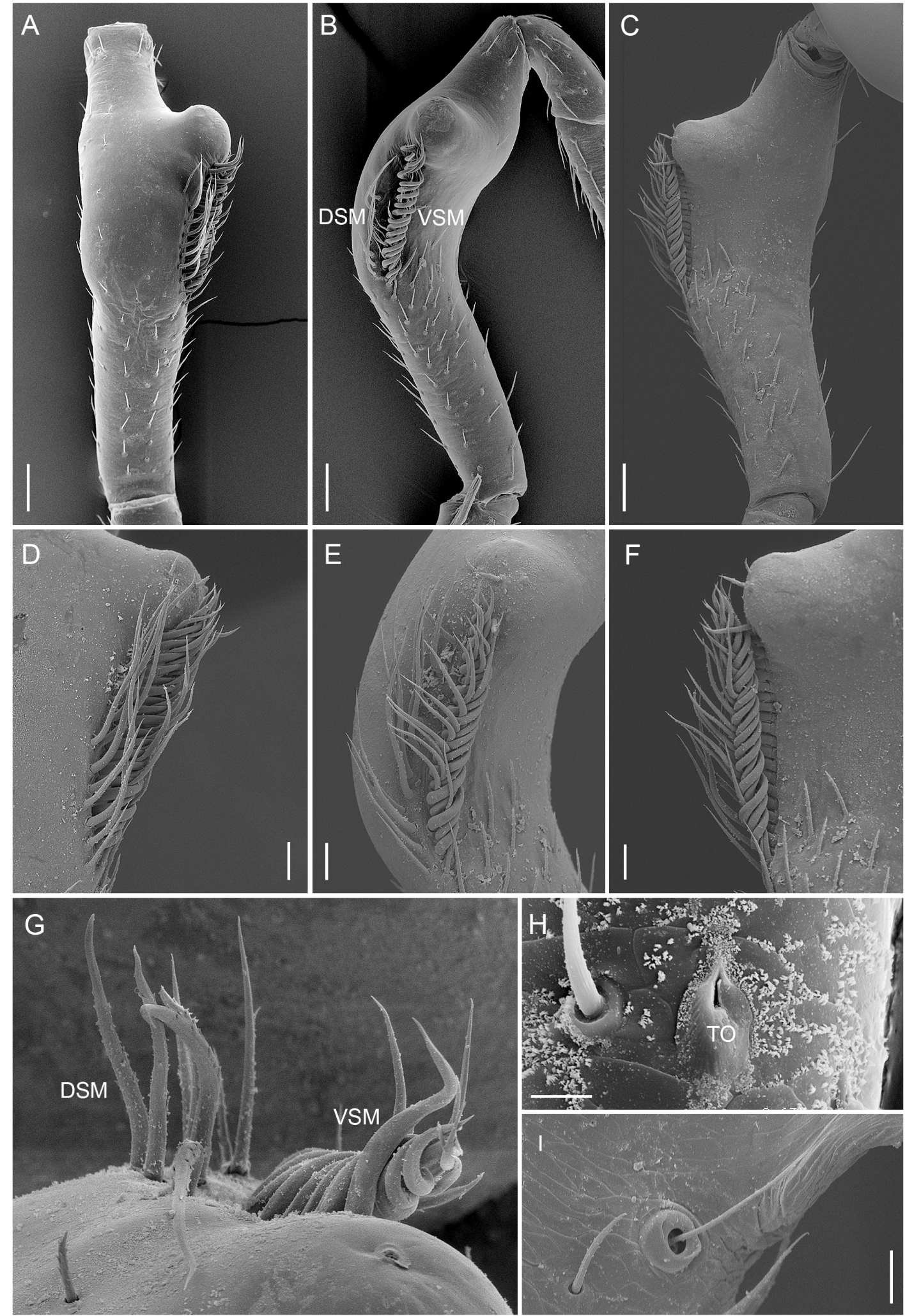

Fig. 4. Xim trenzado gen. et sp. nov. A-B. ECOTAAR-004950. C-F, H-I. ECOTAAR-004962. G. ECOTAAR-004952. A-G. Male left femur I. D-G. Details of macrosetae. A, D. Dorsal view. B, E. Prolateral view. C, F. Ventral view. G. Apical view. H. Tarsal organ of leg I. I. Trichobothrium of retrolateral palpal tibia. Scale bars: $\mathrm{A}-\mathrm{C}=70 \mu \mathrm{m} ; \mathrm{D}-\mathrm{F}=30 \mu \mathrm{m} ; \mathrm{H}=5 \mu \mathrm{m} ; \mathrm{I}=10 \mu \mathrm{m}$. 
like papillae, slightly sclerotized at mesal border, with small membranous protegulum in distal-mesal corner (Figs 2B-C, E-F, H, 3A); sperm duct with tight kink in tegulum (Fig. 3A). Suprategulum curved, continuous with tegulum, visible on prolateral side of alveolus, touching the cymbium, distally turned retrolaterally and ending in a short distal suprategular apophysis, concealed in ventral view by embolic membrane and distal part of protegulum. (Figs 2A-B, D-E, H-I, 3A-B). Radix as long as cymbium, with a spiral tailpiece and heavily sclerotized distal part with a serrated radical ridge (Figs 2A-B, D-E, $\mathrm{H}-\mathrm{I}, 3 \mathrm{~B}$ ), ending in a short spine-like anterior radical process, at origin (in a slightly closed angle) of a very short, straight, less sclerotized embolus, directed proximally (Figs 2B, E, H-I, 3B). Column arising from suprategulum, with embolic membrane developed as an ectal outgrowth from column, both visible among tegulum, tailpiece and radix (Figs 2E, H-I, 3B).

\section{Female}

HaBitus. Carapace, chelicerae and endites light brown with some suffused grey on thoracic part, a narrow diffuse grey band on border of thoracic part, labium and sternum brown. Legs yellow cream, slightly darker from distal half of femur (I and II) or tibiae (III and IV) to tarsi. Opisthosoma yellow cream on the dorsum with a diffused central longitudinal light brown stripe over the $4 / 5$ anterior part, sides and venter light brown; epigastrium and spinnerets yellow-cream (Fig. 1D-F, H).

MeAsurements. Total length 1.73 , carapace 0.75 long, 0.59 wide.

Prosoma. Carapace similar shape to male, except a lower and rounded post-ocular lobe, about half the clypeus height in lateral view, with few sparse hairs (Fig. 1E). Eye diameters and interdistances: AME 0.052, ALE 0.052, PME 0.039, PLE 0.039, AME-AME 0.026, AME-ALE 0.078, PME-PME 0.052, PME-PLE 0.065; AER in frontal view almost straight, slightly recurved, PER in dorsal view almost straight, slightly recurved. Clypeus 0.143 high. Chelicerae with five promarginal (Fig. 1H) and four retromarginal teeth. Sternum 0.44 long, 0.44 width, produced between coxae IV, posterior tip truncated; coxae IV 1.4 times their width apart (Fig. 1F).

Opisthosoma. Elliptical (Fig. 1D-F). Trachea desmitracheate.

Legs. Femur I without prolateral macrosetae. Legs I to IV with one proximal, dorsal macrosetae on each tibia (longer than those of male), without distal, dorsal macroseta; metatarsi and tarsi without macrosetae. Leg formula 1423. Legs measurements: I 2.90 (0.82, 0.23, 0.69, 0.69, 0.47), II 2.77 (0.77, $0.21,0.64,0.68,0.47)$, III $2.18(0.62,0.18,0.43,0.56,0.39)$, IV $2.80(0.79,0.19,0.66,0.71,0.45)$. TmI 0.377, TmIV absent.

EPIGYNUM. With large ventral plate with scattered hairs, with anterior semicircular concavity (ACV) whose rear margin forms a sclerotized border (Fig. 5A, G-H). Dorsal plate in ventral view small, rectangular and transverse, occupying only posterior border of epigynum, with a big anterior lobe, flush with ventral plate, ovoid and slightly wider than long, with a narrowing forming a neck at the level of anterior end of copulatory opening slits, where the anterior lobe joins the ventral plate (Fig. 5A-B, G). Ventral and dorsal plates slightly darker than venter; anterior lobe of dorsal plate yellow-whitish, membranous in appearance (Figs 1F, 5G). Copulatory openings as narrow slits between ventral plate and anterior lobe of dorsal plate (Fig. 5A-B, G). Spermathecae visible ventrally through integument (Figs 1F, 5G). In dorsal view, copulatory duct wide and very short, connected to an asymmetrical, $\mathrm{u}$-shaped, oblong spermatheca with one mesal and one ectal branch, both branches of spermatheca anteriorly directed, ectal branch longer and larger than mesal one, which is almost round (Fig. 5C-F, H). Spermathecae covered by numerous small glandular pores, with bigger pores in base of ectal branch (Fig. 5C-F). Fertilization duct barely visible, arising from postero-mesal part of ectal branch and posteriorly oriented (Fig. $5 \mathrm{H}$ ). 

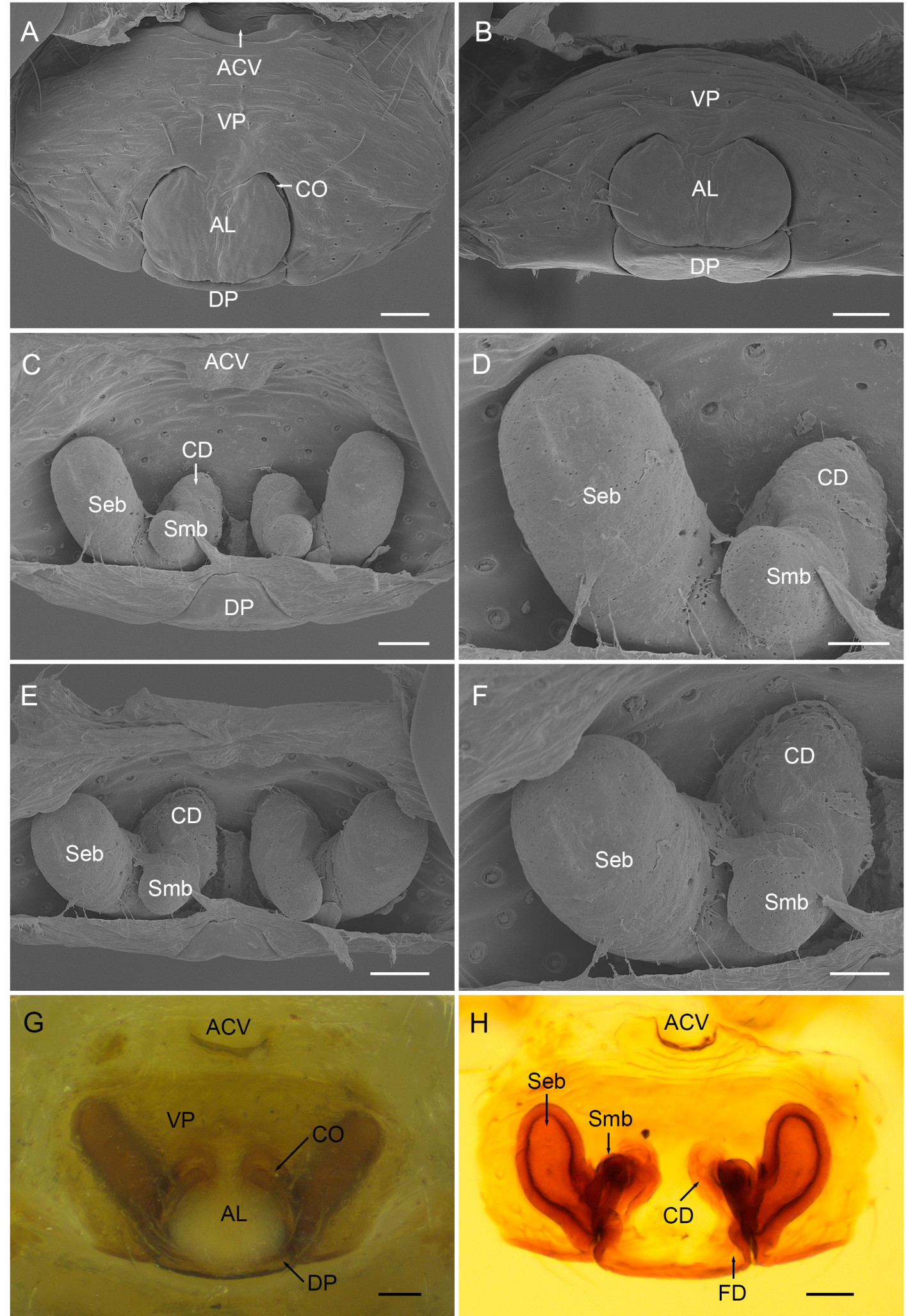

Fig. 5. Xim trenzado gen. et sp. nov.,, , epigynum. A-B. ECOTAAR-005063. C-F. ECOTAAR-005183. A, G. Ventral view. B. Posterior view. C-D, H. Dorsal view. D. Detail of C showing left copulatory duct and spermatheca. E. Antero-dorsal view. F. Detail of E showing left copulatory duct and spermatheca. Scale bars: A-C, E, G-H $=40 \mu \mathrm{m} ; \mathrm{D}, \mathrm{F}=20 \mu \mathrm{m}$. 


\section{Subadult morphology}

Subadult males show enlarged palpal cymbium, palpal tibia with a dorsal protuberance corresponding, in position and shape, to forthcoming prolateral apophysis; carapace with a low post-ocular conical lobe, similar in height to that of adult females; femur I with distal half enlarged and bent to ventral side (less than in adult males), with one series of 9-10 prolateral recumbent macrosetae pointing distally (not interweaved among them), and some subadult males with another series of 2-3 macrosetae located dorsally to first series. In subadult females, carapace shows the post-ocular area slightly higher than the ocular area, and the epigastrium slightly swollen.

\section{Variation}

Males $(\mathrm{n}=6)$. Same color pattern as holotype. Total length 1.49-1.68. Carapace 0.67-0.73 long, 0.560.60 wide, clypeus $0.12-0.16$ high. AME diameter 0.039-0.052, ALE 0.039-0.052, PME 0.033-0.039, PLE 0.033-0.039, AME separation 0.026-0.039, AME-ALE separation 0.052-0.078, PME separation 0.052-0.078, PME-PLE separation 0.065-0.078. Sternum 0.38-0.51 long, 0.41-0.52 wide. Coxae IV separation 0.13-0.19. Leg total length: I 2.34-2.57, II 2.27-2.57, III 1.75-2.00, IV 2.31-2.62. Females $(\mathrm{n}=6)$. Same color pattern as allotype. Total length 1.57-1.91. Carapace 0.67-0.76 long, 0.57-0.62 wide, clypeus 0.10-0.17 high. AME diameter 0.039-0.052, ALE 0.039-0.052, PME 0.039-0.039, PLE 0.039-0.039, AME separation 0.013-0.039, AME-ALE separation 0.052-0.078, PME separation 0.052-0.065, PME-PLE separation 0.052-0.078. Sternum 0.40-0.44 long, 0.43-0.48 wide. Coxae IV separation 0.14-0.21. Leg total length: I 2.61-290, II 2.48-2.75, III 1.97-2.29, IV 2.55-2.84.

\section{Distribution and ecology}

Known only from a small area in the south of Chiapas State, Mexico, the type locality and from Cerro Boquerón, Municipio de Motozintla. One male and one female of this species were collected for the first time by pitfall trap (in January and March 2007, respectively) in a year-round sampling for soil spiders in the type locality. Two years later (2009), when sampling the understory vegetation in the same locality, numerous specimens of both sexes were collected by beating low understory, showing that this species is associated normally to low understory vegetation and was found accidentally on the soil in 2007 (Ibarra-Núñez et al. 2011; Maya-Morales et al. 2012; cited as "Erigoninae sp1"). They were collected from January to August but were more abundant during the dry and cold season (January to beginning of March), when adult numbers were about twice that of juveniles. Human disturbances also affect negatively the abundance of this species (Maya-Morales et al. 2012). Other surveys for spiders were made later in three other cloud forests in the same mountain range (Sierra Madre de Chiapas), but only one female of this species was collected in the nearest of the three studied localities (Cerro Boquerón, $27 \mathrm{~km}$ distance from the type locality, by beating low understory). This makes Xim trenzado gen. et sp. nov. a micro-endemic species, and consequently highly vulnerable to habitat destruction.

\section{Remarks}

In the ventral plate of the epigynum of Xim trenzado gen. et sp. nov., the anterior semicircular concavity (Fig. 5A, G) is very similar to that of Tutaibo velox (Keyserling, 1886) as described and illustrated by Miller (2007: 179, fig. 138f).

\section{Discussion}

Xim trenzado gen. et sp. nov. possesses the two characters that Hormiga (2000) and Miller \& Hormiga (2004) found as synapomorphies supporting the monophyly of the Erigoninae subfamily: presence of one or more tibial apophyses in the male pedipalpalus $(68,70)$, and the loss of the tarsal claw in the female pedipalp. In our consensus cladogram, Xim trenzado gen. et sp. nov. is characterized by nine unambiguous characters (Fig. 7): high cymbium (character 9-1), sperm duct with a tight kink in distal 
tegulum (23-1), short embolus (43-1), prolateral apophysis of male palpal tibia perpendicularly oriented (68-0), with RTA (70-1), male with post-ocular lobe (103-1), male with scaly cheliceral stridulatory striae (117-1), female without proximal dorsomesal macrosetae in palpal tarsus (127-0) and female with one ventroectal macrosetae in palpal tarsus (132-1). In contrast, the clade of Ceratinopsis, Tutaibo and Sphecozone have different states in eight of those characters: cymbium not modified (9-0), sperm duct smooth in distal tegulum (23-0), long embolus (43-0), without RTA (70-0), male without postocular lobe (103-0), male with ridged (117-0, Ceratinopsis and Sphecozone) or imbricated (117-2, Tutaibo) cheliceral stridulatory striae, female with proximal dorsomesal macrosetae in palpal tarsus (127-1) and female with two (132-2, Ceratinopsis and Tutaibo) or three (132-3, Sphecozone) ventroectal macrosetae in palpal tarsus. Only the prolateral apophysis of the male palpal tibia perpendicularly oriented (68-0) is homoplasic being shared between Xim trenzado gen. et sp. nov. and Tutaibo, whereas Ceratinopsis and Sphecozone share a prolateral apophysis of male palpal tibia distally oriented (68-1). In the consensus tree of Frick et al. (2010), the clade including Ceratinopsis, Tutaibo and Sphecozone (clade 62) shares five unambiguous characters: a straight hook paracymbium (12-4), a membranous radix-embolus connection (51-1), one prolateral trichobothria on male's palpal tibia (73-1), male's cheliceral stridulatory striae rows compressed and evenly spaced (118-3) and booklung covers in male nearly smooth (154-3). In our consensus tree (Fig. 7), the clade for Xim, Ceratinopsis, Tutaibo and Sphecozone share only two unambiguous characters, a membranous radix-embolus connection (51-1) and a straight hook paracymbium (12-4) that is lost by Sphecozone (10-1) (Miller \& Hormiga 2004). The clade of Ceratinopsis, Tutaibo and Sphecozone shares now only two unambiguous characters, male palpal tibia with one prolateral trichobothria (73-1, showing homoplasy among Sphecozone species) and male cheliceral stridulatory striae rows compressed and evenly spaced (118-3), showing homoplasy among Sphecozone species). All these changes affected the Bremer support values for the clades 62

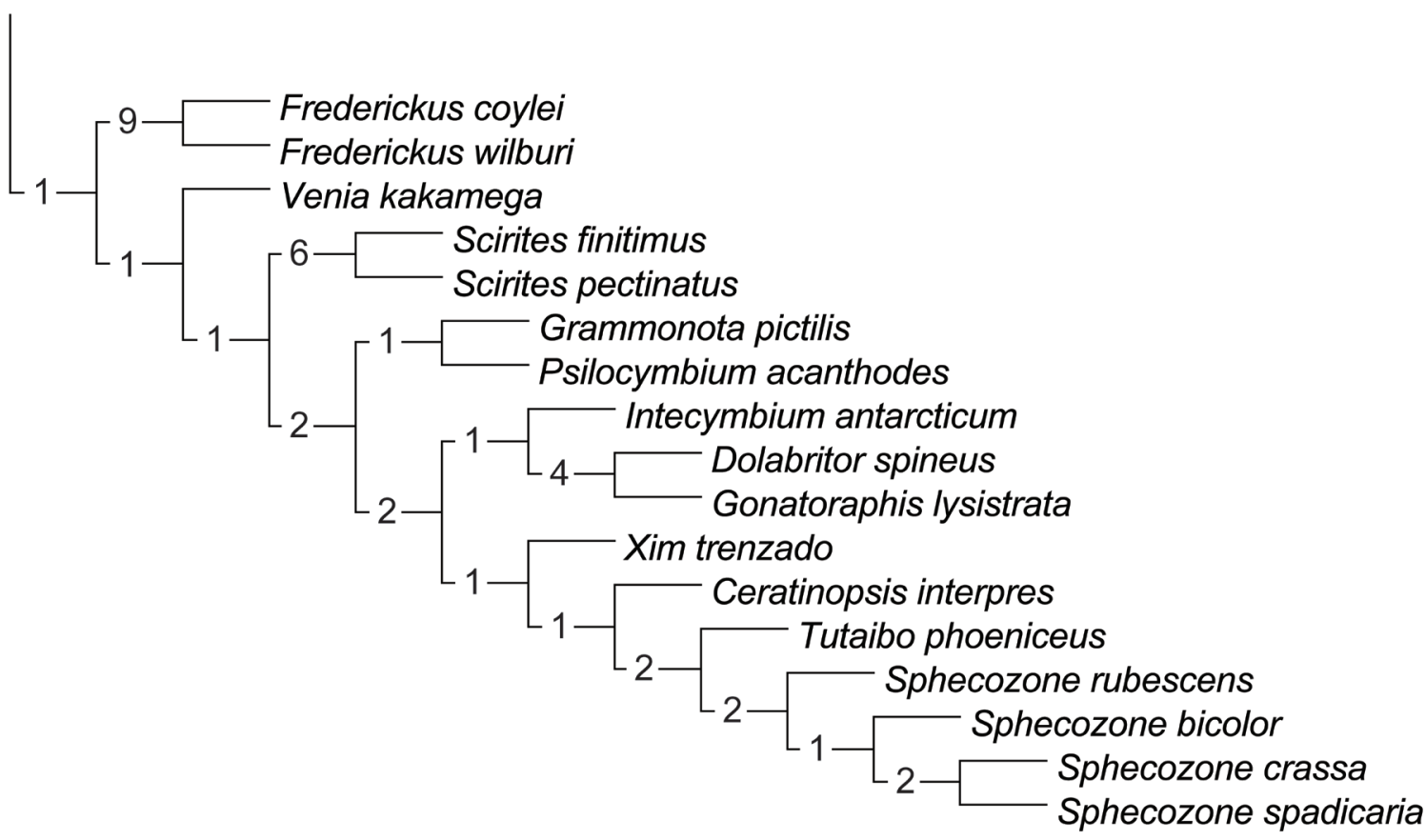

Fig. 6. Strict consensus tree of the eight most parsimonious trees, showing only the distal clades where Xim trenzado gen. et sp. nov. is situated. Tree with Bremer support values noted beside nodes. 


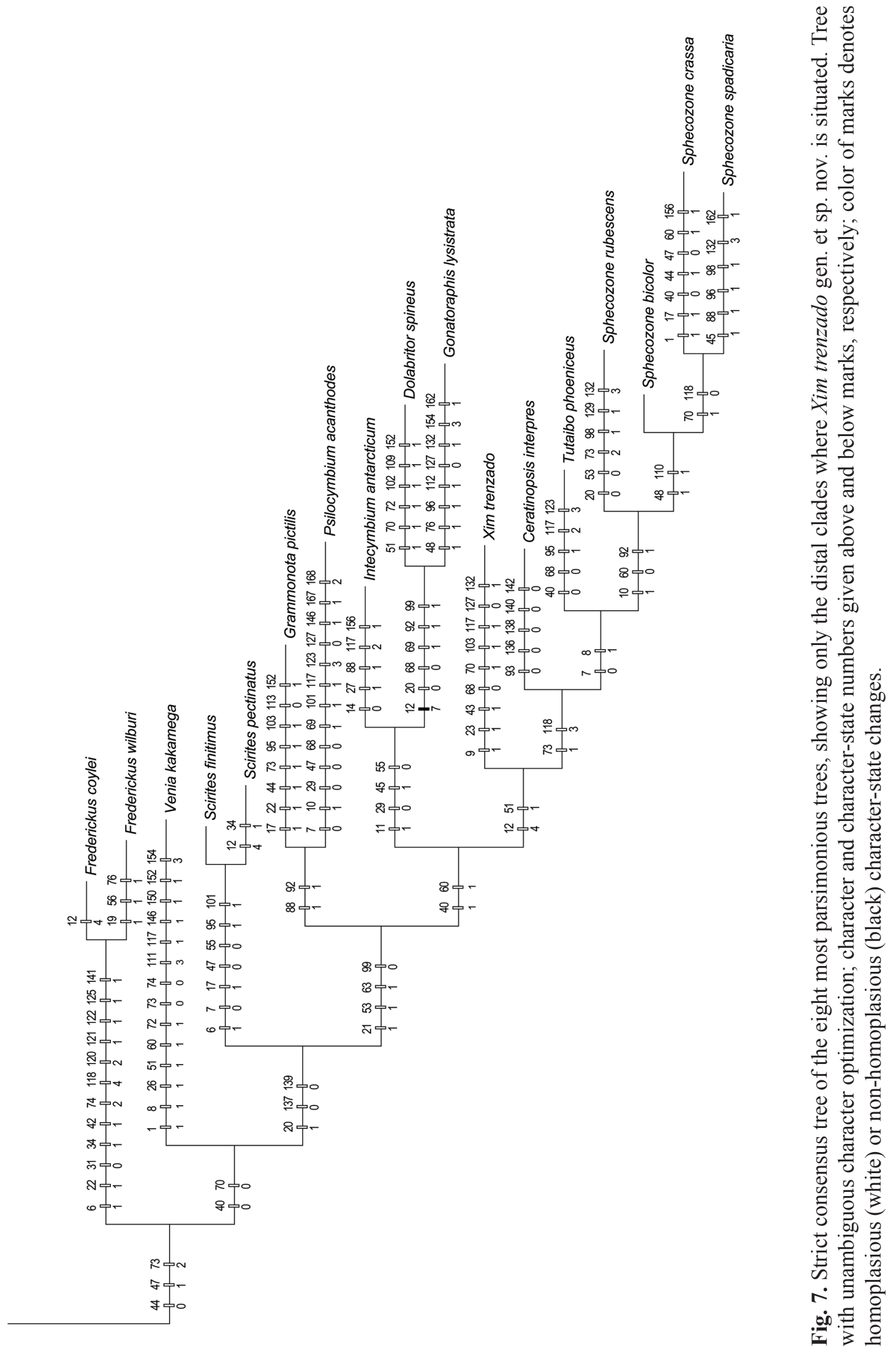


(Ceratinopsis, Tutaibo and Sphecozone) and 63 (Tutaibo and Sphecozone) of Frick et al. (2010) from 4 to 1 , and 3 to 2 , respectively, and the clade including all four genera also having a low support value (1).

The matrix of Miller \& Hormiga (2004) does not include some characters present in Xim trenzado gen. et sp. nov. that could be interesting to compare with other Erigoninae, paracymbium size (large), shape of the spermathecae (u-shaped), and the difference between female and male in the occurrence of prolateral macrosetae on femur I (male with two series, lacking in female). Miller \& Hormiga (2004) found that the absence of prolateral femoral macrosetae on legs I was one of the characters that gives unambiguous support to Erigoninae. Among the Erigoninae, several species of Erigonoplus Simon, 1884 have macrosetae on femur I, but these are located on the ventral side (Millidge 1975). Another Erigoninae, Labullinyphia tersa (Simon, 1894) also has macrosetae on femur I, but these are concentrated in the basal region (Benjamin \& Hormiga 2009). Males of Xim gen. nov. are unique by having macrosetae on the prolateral, distal half of femur I. Lack of these macrosetae in females implies its presence as a sexual character, as in the Erigonoplus spp. and Labullinyphia tersa. The series of macrosetae woven as a braid in adult males is a very rare character, not known until now in any other spider species; it is also puzzling how this braid is formed in the process of the last molt.

The taxonomic knowledge of Linyphiidae species in Mexico has been very limited. Most of the Mexican species were described or recorded from the end of the $19^{\text {th }}$ century to the first half of the $20^{\text {th }}$ century (Banks 1898; Pickard-Cambridge 1902; Gertsch \& Davis 1937, 1946) and later, only two publications by Millidge $(1983,1987)$ added another important number of species. Since then, only five species have been added to the Mexican Linyphiidae fauna (Ibarra-Núñez et al. 2011; Prentice \& Redak 2013; Gómez-Rodríguez et al. 2014; Jiménez et al. 2018; Campuzano Granados et al. 2019). The discovery of a new genus recorded here suggests that the knowledge of the Mexican linyphiids is deficient in general, and particularly from habitats barely explored like the montane cloud forests. It is likely that additional studies of other cloud forests discover new species in this genus, and perhaps other new linyphiid genera.

\section{Acknowledgments}

To Álvaro García, José Antonio López, Estela Sentíes and Eduardo Chamé (ECOSUR) for assistance in collecting spiders. To Guadalupe Nieto, Roxana Bautista and E. Chamé (ECOSUR) for assistance with SEM images. To Gustavo Hormiga (George Washington University) who made comments to an earlier draft of this paper. To the two anonymous reviewers and the topic editor for their helpful comments. To Brian Patrick (Dakota Wesleyan University) who reviewed the English language. This work was supported by the Consejo Nacional de Ciencia y Tecnología (CONACYT) of Mexico, with a grant to GIN (No. 67254) and scholarships to DCV and JMM. Spiders were collected under government permit (SEMARNAT) FAUT-0198 to G. Ibarra-Núñez.

\section{References}

Arnedo M.A., Hormiga G. \& Scharff N. 2009. Higher-level phylogenetics of linyphiid spiders (Araneae, Linyphiidae) based on morphological and molecular evidence. Cladistics 25 (3): 231-262.

https://doi.org/10.1111/j.1096-0031.2009.00249.x

Banks N.A. 1898. Arachnida from Baja California and other parts of Mexico. Proceedings of the California Academy of Sciences $3^{\text {rd }}$ Series 1: 205-308.

Benjamin S.P. \& Hormiga G. 2009. Phylogenetic placement of the enigmatic genus Labullinyphia van Helsdingen, 1985, with redescription of Labullinyphia tersa (Simon, 1894) from Sri Lanka (Araneae: Linyphiidae). Contributions to Natural History 12: 161-181. 
Campuzano Granados E.F., Ibarra Núñez G., Gómez Rodríguez J.F. \& Angulo Ordoñes G.G. 2019. Spiders (Arachnida: Araneae) of the tropical mountain cloud forest from El Triunfo Biosphere Reserve, Mexico. Acta Zoológica Mexicana (n.s.) 35: 1-19. https://doi.org/10.21829/azm.2019.3502092

Chamberlin R.V. 1924. Expedition of the California Academy of Sciences to the Gulf of California in 1921. The spider fauna of the shores and islands of the Gulf of California. Proceedings of the California Academy of Sciences $4^{\text {th }}$ Series 12 (28): 561-694.

Available from https://www.biodiversitylibrary.org/part/53461\#/summary [accessed 17 Dec. 2020].

Dondale C.D. 1959. Definition of the genus Grammonota (Araneae: Erigonidae), with descriptions of seven new species. The Canadian Entomologist 91: 232-242. https://doi.org/10.4039/Ent91232-4

Draney M.L. \& Buckle D.J. 2017. Linyphiidae. In: Ubick D., Paquin P., Cushing P.E. \& Roth V.D. (eds) Spiders of North America: An Identification Manual. $2^{\text {nd }}$ Ed.: 137-175. American Arachnological Society, Keene, NH, USA.

Dupérré N. \& Paquin P. 2007. Revision of the North American genus Scirites (Araneae, Linyphiidae). Zootaxa 1460 (1): 47-58. https://doi.org/10.11646/zootaxa.1460.1.4

Frick H. \& Muff P. 2009. Revision of the genus Caracladus with the description of Caracladus zamoniensis spec. nov. (Araneae, Linyphiidae, Erigoninae). Zootaxa 1982 (1): 1-37.

https://doi.org/10.11646/zootaxa.1982.1.1

Frick H., Nentwig W. \& Kropf C. 2010. Progress in erigonine spider phylogeny-the Savignia-group is not monophyletic (Araneae: Linyphiidae). Organisms Diversity and Evolution 10: 297-310. https://doi.org/10.1007/s13127-010-0023-1

Gertsch W.J. \& Davis L.I. 1937. Report on a collection of spiders from Mexico. I. American Museum Novitates 961: 1-29. Available from http://hdl.handle.net/2246/3861 [accessed 17 Dec. 2020].

Gertsch W.J. \& Davis L.I. 1946. Report on a collection of spiders from Mexico. V. American Museum Novitates 1313: 1-11. Available from http://hdl.handle.net/2246/4478 [accessed 17 Dec. 2020].

Goloboff P.A. \& Catalano S.A. 2016. TNT version 1.5, including a full implementation of phylogenetic morphometrics. Cladistics 32 (3): 221-238. https://doi.org/10.1111/cla.12160

Gómez-Rodríguez J.F., Montaño H., Ibarra-Núñez G. \& Salazar O.C.A. 2014. Arácnidos (excepto ácaros) de Tamaulipas: listado actualizado y algunos registros nuevos. In: Correa S.A., Horta V.J. V., García J.J. \& Barrientos L.L. (eds) Biodiversidad Tamaulipeca Vol. 2, Núm. 2: 51-57, 64-74. Tecnológico Nacional de México - Instituto Tecnológico de Ciudad Victoria, Tamaulipas, México.

Hoffmann A. 1976. Relación Bibliográfica Preliminar de las Arañas de México (Arachnida: Araneae). Universidad Nacional Autónoma de México, México, D.F.

Hormiga G. 2000. Higher level phylogenetics of Erigonine spiders (Araneae, Linyphiidae, Erigoninae). Smithsonian Contributions to Zoology 609: 1-160. https://doi.org/10.5479/si.00810282.609

Ibarra-Núñez G., Maya-Morales J. \& Chamé-Vázquez D. 2011. Las arañas del bosque mesófilo de montaña de la Reserva de la Biosfera Volcán Tacaná, Chiapas, México. Revista Mexicana de Biodiversidad 82: 1183-1193. https://doi.org/10.22201/ib.20078706e.2011.4.736

Jiménez M.L., Palacios-Cardiel C., Maya-Morales J. \& Berrian J.E. 2018. Nuevos registros de arañas (Arachnida: Araneae) para la Región del Cabo, península de Baja California, México. Acta Zoológica Mexicana (n.s.) 34: 1-13. https://doi.org/10.21829/azm.2018.3412159

Llorente J., González Soriano E., García Aldrete A. \& Cordero C. 1996. Breve Panorama de la Taxonomía de Artrópodos en México. In: Llorente J., García Aldrete A. \& González Soriano E. (eds) Biodiversidad, 
Taxonomía y Biogeografía de Artrópodos de México: Hacia una Síntesis de su Conocimiento: 3-14. Instituto de Biología, UNAM, México, D.F.

Maya-Morales J., Ibarra-Núñez G., León-Cortés J.L. \& Infante F. 2012. Understory spider diversity in two remnants of tropical montane cloud forest in Chiapas, Mexico. Journal of Insect Conservation 16 (1): 25-38. https://doi.org/10.1007/s10841-011-9391-x

Miller J.A. 2005a. Cave adaptation in the spider genus Anthrobia (Araneae, Linyphiidae, Erigoninae). Zoologica Scripta 34: 565-592. https://doi.org/10.1111/j.1463-6409.2005.00206.x

Miller J.A. 2005b. A redescription of Porrhomma cavernicola Keyserling (Araneae, Linyphiidae) with notes on appalachian troglobites. Journal of Arachnology 33 (2): 426-438.

https://doi.org/10.1636/04-51.1

Miller J.A. 2007. Review of Erigonine spider genera in the Neotropics (Araneae: Linyphiidae, Erigoninae). Zoological Journal of the Linnean Society 149 (Supp.1): 1-263.

https://doi.org/10.1111/j.1096-3642.2007.00233.x

Miller J.A. \& Hormiga G. 2004. Clade stability and the addition of data: a case study from erigonine spiders (Araneae: Linyphiidae, Erigoninae). Cladistics 20 (5): 385-442.

https://doi.org/10.1111/j.1096-0031.2004.00033.x

Millidge A.F. 1975. A taxonomic revision of the genus Erigonoplus Simon 1884 (Araneae: Linyphiidae: Erigoninae). Bulletin of the British Arachnological Society 3 (4): 95-100.

Millidge A.F. 1980. The erigonine spiders of North America. Part 2. The genus Spirembolus Chamberlin (Araneae: Linyphiidae). Journal of Arachnology 8 (2): 109-158. Available from http://www.americanarachnology.org/JoA_tocs/JOA_contents_v8n2.html [accessed 13 Jan. 2021].

Millidge A.F. 1983. The erigonine spiders of North America. Part 6. The genus Walckenaeria Blackwall (Araneae, Linyphiidae). Journal of Arachnology 11 (2): 105-200. Available from http://www.americanarachnology.org/JoA_tocs/JOA_contents_v11n2.html [accessed 13 Jan. 2021].

Millidge A.F. 1987. The erigonine spiders of North America. Part 8. The genus Eperigone Crosby and Bishop (Araneae, Linyphiidae). American Museum Novitates 2885: 1-75.

Available from http://hdl.handle.net/2246/5129 [accessed 17 Dec. 2020].

Nixon K.C. 2002. Winclada, Version 1.00.08. Program and documentation. Published by the author, Ithaca, NY, USA. Available from http://www.cladistics.com [accessed 17 Dec. 2020].

Paquin P., Dupérré N., Buckle D.J. \& Crawford R.L. 2008. A new spider genus from North America: Frederickus (Araneae: Linyphiidae). Animal Biology 58 (1): 91-112.

https://doi.org/10.1163/157075608X303663

Pickard-Cambridge F.O. 1902. Arachnida. Araneidea and Opiliones. Vol. II. In: Godman F.C. \& Salvin O. (eds) Biologia Centrali-Americana: 305-316. London. https://doi.org/10.5962/bhl.title.730

Prentice T.R. \& Redak R.A. 2013. A new species of the spider genus Eridantes Crosby \& Bishop from the southwestern United States and mainland Mexico with a revised diagnosis of the genus (Araneae, Linyphiidae, Erigoninae). Zootaxa 3616 (4): 357-366. https://doi.org/10.11646/zootaxa.3616.4.4

Russell-Smith A. \& Stork N. 1994. Abundance and diversity of spiders from the canopy of tropical rainforests with particular reference to Sulawesi, Indonesia. Journal of Tropical Ecology 10 (4): 545558. https://doi.org/10.1017/S0266467400008221

Seyfulina R.R. \& Jocqué R. 2009. Venia kakamega gen. n., sp. n., a new, canopy-dwelling Afrotropical erigonine spider (Araneae, Linyphiidae). Journal of Afrotropical Zoology 5: 3-13. 
Sørensen L.L. 2004. Composition and diversity of the spider fauna in the canopy of a montane forest in Tanzania. Biodiversity and Conservation 13: 437-452. https://doi.org/10.1023/B:BIOC.0000006510.49496.1e

Wang F., Ballesteros J.A., Hormiga G., Chesters D., Zhan Y., Sun N., Zhu C., Chen W. \& Tu L. 2015. Resolving the phylogeny of a speciose spider group, the family Linyphiidae (Araneae). Molecular Phylogenetics and Evolution 91: 135-149. https://doi.org/10.1016/j.ympev.2015.05.005

WSC 2020. World Spider Catalog version 21.0. Natural History Museum, Bern.

Available from http://wsc.nmbe.ch [accessed 5 Feb. 2020].

Zhao Q. \& Li S. 2017. Callosa gen. n., a new troglobitic genus from southwest China (Araneae, Linyphiidae). ZooKeys 703: 109-128. https://doi.org/10.3897/zookeys.703.13641

Manuscript received: 13 July 2020

Manuscript accepted: 9 November 2020

Published on: 19 January 2021

Topic editor: Rudy Jocqué

Desk editor: Pepe Fernández

Printed versions of all papers are also deposited in the libraries of the institutes that are members of the EJT consortium: Muséum national d'histoire naturelle, Paris, France; Meise Botanic Garden, Belgium; Royal Museum for Central Africa, Tervuren, Belgium; Royal Belgian Institute of Natural Sciences, Brussels, Belgium; Natural History Museum of Denmark, Copenhagen, Denmark; Naturalis Biodiversity Center, Leiden, the Netherlands; Museo Nacional de Ciencias Naturales-CSIC, Madrid, Spain; Real Jardín Botánico de Madrid CSIC, Spain; Zoological Research Museum Alexander Koenig, Bonn, Germany; National Museum, Prague, Czech Republic. 